Особистісно-професійне зростання вчителя сільської школи в умовах неперервної освіти [Електронний ресурс]/ Н. В. Бухлова. - Режим доступу : http://ippo.dn.ua/assets/Uploads/ Vseukrainskyforum/ Buhlova.doc 3. Воложина А. В. Сравнительный анализ профессионального самообразования сельского и городского учителя [Електронний ресурс]/ A. В. Воложина. - Режим доступу : http://nsportal.ru/vuz/psikhologicheskie-nauki/library// sravnitelnyy-analiz-professionalnogosamoobrazovaniy 4. Гончаренко С. У. Український педагогічний словник / Семен Гончаренко. - К. : Либідь, 1997. - 376 с. 5. Гуц 3. Самоосвіта - самоціль чи необхідність / З. Гуц // Завуч. - 2005. - № 28. - С. 7. . Дзега В. Д. Сільська малокомплектна школа в умовах експериментальної діяльності / В. Д. Дзега // Особливості інноваційної діяльності сільської малокомплектної школи : матеріали науково-практичної конференції (Черкаси). 2010. 7. Радченко А. С. Моніторинг професійної педагогічної компетентності вчителя/ А. Є. Радченко // Управління школою. - 2005. - № 35-36. - С. 12-15.

\title{
ПЕДАГОГІЧНА ТЕХНОЛОГІЯ ФОРМУВАННЯ ЛІНГВІСТИЧНОӤ КОМПЕТЕНТНОСТІ МАЙБУТНЬОГО ВЧИТЕЛЯ ПОЧАТКОВОЇ ШКОЛИ
}

Мамчич О. Б., Калініна І. П. Педагогічна технологія формування лінгвістичної компетентності майбутнього вчителя початкової школи.

Статтю присвячено дослідженню проблеми формування лінгвістичної компетентності майбутніх учителів початкової школи у вищих педагогічних навчальних закладах. Обгрунтовано педагогічні умови та розроблено систему формування мовної компетентності, що передбачає методику формування, комплекс тем і завдань теоретичного і практичного характеру.

Ключові слова: лінгвістична компетентність, комунікативна компетентність, лінгвостилістичний аналіз тексту.

Мамчич О. Б., Калинина И. П. Педагогическая технология формирования лингвистической компетентности будущего учителя начальной школы.

Статья посвящена исследованию проблемы формирования лингвистической компетентности будущих учителей начальной школы в высших педагогических учебных заведениях. Обоснованы педагогические условия и разработана система формирования языковой компетентности, которая включает методику формирования, комплекс тем и заданий теоретического и практического характера.

Ключевые слова: лингвистическая компетентность, коммуникативная компетентность, лингвостилистический анализ текста.

Mamchich O. B., Kalinina I. P. Pedagogical technology of forming the linguistic competence of future teacher of primary school.

The article is devoted to the research of forming of linguistic competence of future elementary school teachers in pedagogical higher schools. The pedagogical conditions of forming linguistic competence, the system of forming includes the forming methods, the theoretical and practical complex of subjects and tasks.

Key words: linguistic competence, communicative competence, linguistic analysis of texts. 
Основним напрямком сучасної вищої педагогічної освіти в Україні є орієнтація на розвиток індивідуальних особливостей особистості майбутнього фахівця. Такий напрямок передбачає створення відповідних умов для постійного підвищення рівня інтелектуальних якостей особистості кожного студента під час вивчення дисциплін мовного циклу у ВНЗ. Процес розвитку інтелекту безпосередньо пов'язаний із процесом формування лінгвістичної компетентності майбутнього педагога початкової школи. Вивчення виразних можливостей слова як складника синтаксичної будови тексту позитивно впливає на мовну поведінку вчителя. Саме так реалізується основна мета викладання мовних дисциплін у вищій педагогічній школі - підвищення комунікативної культури майбутнього спеціаліста, що є невід’ємним складником його професійної діяльності, показником сформованої лінгвістичної компетентності, оскільки вчитель $є$ передовсім специфічною мовною особистістю. Звідси й актуальність дослідження.

Лінгводидакти наголошують, що коло лінгвопедагогічних і методичних проблем, пов'язаних 3 викладанням мовних дисциплін в аудиторії нефілологів, надзвичайно широке і перебуває нині в стадії осмислення - як наукового, так і методичного, отже, від того, за допомогою яких методик навчатиметься мови майбутній учитель початкової школи у ВНЗ, залежить рівень організації та структурна модель його знань, лінгвістична орієнтованість, а основне - усвідомлення ним синтаксичної та семантичної природи речення як однієї з основних одиниць зв'язного мовлення.

Недостатній ступінь розробленості означеної проблеми в сучасній педагогічній науці, брак нестандартних авторських методик вивчення синтаксису художнього тексту не завжди дозволяє студентові усвідомити лінгвістичні явища в неперервному ланцюжку пізнання, мислення, сформувати вміння та навички, які сприятимуть розвитку мови та мовлення, набуттю базових теоретичних знань, що і $є$ передумовою лінгвістичної компетентності. Засвідчити необхідність використання лінгвостилістичного аналізу тексту як однієї із синтаксичних форм та одиниць мови, виняткову важливість його для розвитку мислення та мовлення педагогічної мовної особистості, якою є вчитель початкової школи, означає засвідчити відповідний рівень його пізнання, інтелекту, рівня професійної майстерності. Задля найбільш повного представлення результатами дослідження шляхів формування лінгвокомпетентності майбутнього вчителя нами було проведено лінгвопедагогічний експеримент.

Основними дидактичними та психолого-педагогічними умовами нашого дослідження вважаємо актуалізацію творчих методів вирішення лінгвістичних завдань пошукового характеру, постійне створення проблемних ситуацій пізнавального типу, а основне - визначення стимулів для творчого самопочуття та особистісного вдосконалення студента для найбільш повної реалізації його індивідуальності. Отже, індивідуальність студента як мовної особистості $є$ основою навчального процесу. 3 огляду на це завданнями дослідження $\epsilon$ перевірка впливу індивідуальних форм і методів роботи над синтаксичним аналізом авторського тексту на формування лінгвістичної компетентності майбутнього вчителя початкової школи у педагогічному ВНЗ. Здійснення дослідження, спрямованого на «особистісну індивідуалізацію», а також постійна «індивідуалізація ситуацій», сприяють розвиткові мовлення студентів, «комунікативної мотивації», удосконаленню рівня наявних теоретичних знань, посиленню особистого відчуття потреби нових знань, особистісному усвідомленню ними рівня своєї лінгвістичної компетентності.

Свого часу видатний філософ I. Кант зазначав, що душа володіє трьома здібностями: здібністю пізнання почуття задоволення, незадоволення та здібністю 
бажання. Ураховуючи те, наскільки низьким є зараз потяг тих, хто навчається, до знань взагалі, доводиться майже краплинами збирати і накопичувати те цінне, що мали у своєму досвіді дореволюційна та постреволюційна системи освіти, доробки сучасних педагогів-новаторів, а також досягнення освітянської галузі країн Заходу. Викликати у студентів постійну потребу пізнання, а також почуття невдоволення собою та бажання перетнути бар'єр лінгвістичної необізнаності має бути основним завданням сучасного навчального процесу у ВНЗ, особливо педагогічному. Прикро, але сучасна школа подекуди відбиває бажання навчатися, майже нівелює особистість, а досить часто і нівечить прагнення юної душі бути не такою, як усі. Цю ситуацію повинна подолати нова система навчання та виховання у вищих навчальних закладах. Уважаємо, що педагогічна вища школа, саме запроваджуючи окремі наробки експериментального авторського навчання, здатна подолати утворені роками стереотипи мислення й неадекватного ставлення до всього нового та незвичного, адже стандарти вищої освіти не є догмами, вони - напрямки для розвитку, вдосконалення та активного впровадження їх у життя, i результати експерименту довели правильність обраного нами шляху. Підсумки нашого дослідження знайшли відповідне відображення в деяких допоміжних методах (педагогічне спостереження, анкетування, опитування, співбесіда, інтерв'ювання, моделювання, тренінг, рейтингова система оцінювання знань).

Основні вимоги нашого лінгвопедагогічного дослідження продиктовані поетапністю його складників, детальністю аналізу кожної характеристики, функціональністю виявів окремих рис різноманітних синтаксичних одиниць в авторському тексті, а також аналізом та синтезом ілюстративного практичного матеріалу, який було обрано нами для підтвердження основних теоретичних принципів.

Отже, метою нашого дослідження стало практичне обгрунтування педагогічних умов формування лінгвістичної компетентності майбутніх учителів та вироблення таких спеціальних прийомів для організації процесу набуття теоретичних знань i практичних умінь та навичок, що сприяють підвищенню рівня мовної обізнаності, культури мови і мовлення.

Основним надбанням нашого дослідження став єдиний комплекс логічних i послідовно здійснених індивідуально орієнтованих інтерактивних технологій, що складають принципово нову раціональну систему структури теоретичних знань та практичних навичок для формування лінгвістичної компетентності майбутніх фахівців.

Місцем проведення дослідження стали лекційні та практичні заняття курсів сучасних української та російської мов, спецкурсу порівняльної граматики української та російської мов на факультеті початкового навчання Чернігівського національного педагогічного університету.

Оскільки будь-яка педагогічна технологія має відповідати основним критеріям технологічності, до яких належать: концептуальність, системність, керованість, ефективність, відтворюваність, ми намагалися максимально зосередити увагу на такому плануванні та практичному здійсненні нашого дослідження, щоб усі критерії, визначені вище, були враховані. Так, наприклад, концептуальність характеризує відповідний обсяг наших поглядів, ідей, думок щодо розуміння складного процесу формування лінгвістичної компетентності майбутніх учителів та визначається основним задумом дослідження. Системність передбачає врахування нами визначеного плану послідовного опанування навчального синтаксичного матеріалу за 
відповідними дидактичними принципами (від простого до складного, від часткового до загального, від відомого до невідомого), логічність та поступовість його викладення згідно 3 концептуальністю дослідження. Керованість процесу практичного формування лінгвістичної компетентності майбутнього вчителя полягає в постійній коригованості нами цього процесу та спрямуванні його згідно з основною метою, концепцією, системою відповідних завдань, що забезпечує оптимальність результатів. Ефективність від практичного впровадження інноваційних методик засвідчує результати досягнення мети нашого концептуально визначеного, системного, керованого дослідження і характеризується мірою позитивних наслідків, що отримуємо від застосування нестандартних технологій, та системою відповідних висновків на користь саме таких методик на відміну від звичайних. Відтворюваність полягає у творчому усвідомленні та наслідуванні студентами наших концептуально визначених, системних, керованих, ефективних лінгвопедагогічних технологій задля отримання найбільш продуктивного результату, основним показником якого $\epsilon$ лінгвістична компетентність майбутнього вчителя. Отже, означені складники критеріїв педагогічної технологічності ми водночас вважаємо основами формування самої лінгвістичної компетентності. Адже компетентність у будь-якій галузі, зокрема й лінгвістичній, складається під впливом обов'язкового усвідомлення ії визначеної концептуальності, відповідної системності ऑii набуття, передбачає постійну керованість цього процесу викладачем, який використовує найбільш ефективні інноваційні технології, та, нарешті, іії відтворюваність, що виявляється у відповідному рівні мовної обізнаності, формуванні лінгвістичного чуття, комунікативній культурі майбутнього фахівця.

Варто зазначити також, що мають місце різні рівні інновацій: організаційний, навчальний, виховний, професійний, контрольний та оцінювальний. Ми, намагаючись творчо підходити до досліджуваної проблеми, спрямували роботу саме з урахуванням специфіки означених рівнів. Адже визначені параметри мали засвідчити наявний рівень лінгвокомпетентності майбутнього вчителя і надати нового імпульсу для пошуку умов його оптимуму. Оскільки перш ніж розпочинати дослідження, слід підготувати студентську аудиторію до відповідного його сприймання. Нами було створено такі адаптаційні умови, які надали змогу студентам досить швидко i водночас уважно поставитися до роботи, відчути свою особисту причетність до цього процесу, а тому і свідомо сприйняти його. Цей факт також довів правильність обраного нами шляху і зайвий раз переконав: що раніше викладач починає «творити» і моделювати свою, неповторну, індивідуальну, авторську ситуацію формування мовних знань, тобто лінгвістичної компетентності, то швидше створюються сприятливіші умови ії̈ набуття майбутнім учителем початкової школи.

Отже, система завдань щодо аналізу особливостей стилю та синтаксичної манери різних письменників передбачала пошук студентами тих текстів, які найбільш повно ілюстрували б визначену мету нашої методики, та сприяла отриманню найбільш позитивних результатів. Оскільки курс «Дитяча література» $є$ єдиною та основною дисципліною літературознавчого характеру на факультеті початкового навчання, для аналізу синтаксичних особливостей авторського тексту ми обирали переважно прозові та поетичні твори за програмою. Для аналізу було ще запропоновано інші твори української та російської літератури тих авторів, яких студенти обирали за власним бажанням. Означена ситуація пояснювалась тим, що 3-поміж різних авторів зустрічалися й такі, що писали тільки для дітей, i такі, чиї твори були розраховані на дорослу аудиторію. Такий підхід був визначений нами свідомо, оскільки аналіз синтаксичних особливостей 
авторського тексту обов'язково передбачає порівняння як один із методів дослідження, а головне - забезпечує більш глибоке проникнення у творчу лабораторію письменника.

Ураховуючи той факт, що інтелектуальний рівень сучасного вчителя є основним показником його професійної придатності, нашим пошуком ми намагалися дещо розширити межі програми і надати змогу майбутнім фахівцям виявити особистісні лінгвістичні характеристики рівня свого інтелекту якомога повно. До того ж, ми було передбачили виявлення рівня лінгвістичного мислення студентів, зорієнтованості в потоці тих синтаксичних особливостей, які завжди пропонує будь-який текст взагалі та окремі його одиниці зокрема. Що ж до програмного матеріалу, він формально обмежувався темами синтаксису, від вивчення словосполучення до складного синтаксичного цілого. Але, аналізуючи синтаксичні особливості авторського тексту, практично неможливо обійтися без відповідних знань морфології, лексики, а, враховуючи рівень грамотності студентів, - i без повторення орфографії та пунктуації. Коригування рівня зв'язного мовлення майбутнього вчителя неодмінно забезпечувало доцільність згадування тем орфоепії, фонетики тощо. Умови роботи створювали теоретичне та практичне підгрунтя і задля подальшого вивчення тем пунктуації.

Отже, залежно від етапів вивчення теоретичного матеріалу та практичного його застосування майбутніми фахівцями початкової школи, найбільш оптимальними слід визнати такі творчі завдання, які дозволили студентам найбільш повно виявляти здатність до лінгвістичного мислення та демонструвати свідомий рівень особистої мовної компетентності. Оскільки наявний прямий зв'язок між рівнем творчого мислення й адекватністю його відтворюваності в результатах реальної діяльності особистості, той, хто вміє виразити себе засобами мови, продуктивніше працюватиме й адаптуватимется до довкілля. Саме тому творчі завдання синтаксичного аналізу авторського тексту складалися нами 3 урахуванням інтересів аудиторії й окремих студентів, специфіки підготовки педагогів за спеціальністю «Початкове навчання», певного педагогічного досвіду, набутого ними під час проходження практики (у пасивній та активній іï формах) у початковій школі. Отже, викристалізувалися певні моделі блоків проблемних завдань, які передбачали: а) кількість теоретичних питань за темою; б) відповідну кількість речень, які виконували б роль ілюстративного матеріалу; в) допоміжні завдання творчого характеру, що залежали від послідовності вивчення матеріалу. Моделі блоків завдань стали також основою тестування як одного 3 незвичних та водночас цікавого для студентів сучасного допоміжного навчально-контролюючого методу, адже тести мають велику практичну значущість у психології освіти. Означені блоки завдань коригувалися рейтинговою системою оцінювання знань.

Окремі моделі індивідуально орієнтованих творчих завдань, що їх було визначено метою, методиками та умовами нашого дослідження, мали такий вигляд:

1) визначити естетичні засоби структурно-семантичної одиниці словосполучення у прозових та поетичних текстах;

2) віднайти в тексті словосполучення, охарактеризувати їх залежно від лексикограматичних ознак; пояснити, чому автор використовує саме такі моделі словосполучень;

3) визначити в тексті прості та складні словосполучення, проаналізувати структуру моделей таких словосполучень; дібрати з інших текстів словосполучення за визначеними моделями;

4) окремі словосполучення трансформувати у прості речення; довести, чому 
інколи зробити це неможливо; увести їх у текст зв'язного мовлення, використовуючи приклади;

5) віднайти у текстах випадки синтаксичного зв'язку керування згідно 3 нормами сучасної української мови та нормами сучасної російської мови; пояснити граматичні ознаки цих форм;

6) навести приклади простих речень за визначеними моделями їхніх типів за структурою, метою висловлення, модальністю, експресивною забарвленістю; пояснити своєрідність авторської естетичної моделі; аргументувати, чи вдалося авторові реалізувати свої творчі задуми мовними засобами;

7) віднайти в тексті найбільш синтаксично типові зразки підметів; схарактеризувати, які граматичні форми підмета використовує автор у своїх творах; які речення (двоскладні чи односкладні) превалюють у тексті;

8) віднайти в текстах різні типи неповних речень залежно від мовленнєвого контексту, діалогу, ситуації; визначити, чи використовує автор такі речення взагалі та з якою метою;

9) віднайти в тексті складне речення (СР); визначити кількість предикативних одиниць, тип за засобами зв'язку: складносурядне (ССР), складнопідрядне (СПР), безсполучникове (БСР), складні синтаксичні конструкції (ССК) з різними видами зв'язку; визначити, які речення найчастіше використовує автор;

10) пояснити функції розділових знаків у реченнях тексту; скласти речення за визначеними моделями; зробити повний пунктуаційний аналіз речень авторського тексту.

Така система проблемних завдань надає змогу майбутнім педагогам синтезувати свої теоретичні знання синтаксичного матеріалу, практично інтерпретувати окремі особливості авторського письма для розуміння тієї специфіки граматичного навантаження, якою завжди відрізняється текст.

Основні висновки нашого дослідження підтвердили тезу про те, що рівень сформованості лінгвістичної компетентності майбутніх учителів початкової школи значно зросте за умов: а) змодельованого добору текстового мовного матеріалу 3 урахуванням орієнтації майбутніх педагогів на досягнення комунікативної мети вивчення синтаксису української та російської мов; б) засвоєння студентами методики вивчення композиційних структур професійно зорієнтованого аналізу авторського тексту, що передбачає використання системи спеціальних індивідуальних інтегративних синтаксичних завдань проблемного характеру. У сукупності це підвищило мотивацію опанування студентами майбутнього фаху, стимулювало навчальну діяльність, сприяло набуттю лінгвістичного досвіду. Дослідження довело ефективність запропонованої системи індивідуально орієнтованих моделей аналізу синтаксису авторського тексту, що було спрямовано на формування лінгвістичної компетентності майбутніх фахівців початкової школи у вищих педагогічних навчальних закладах.

Виходячи 3 результатів дослідження, можна рекомендувати: а) у школіознайомлювати учнів 3 елементами лінгвостилістичного аналізу особливостей авторського синтаксису, розвивати уміння та навички задля підвищення їх мовної та мовленнєвої культури; б) у ВНЗ - упроваджувати в практику вивчення мовних дисциплін лінгвостилістичний аналіз синтаксичних особливостей авторського тексту, ураховуючи специфіку курсів і психолого-педагогічні умови процесу навчання. 


\section{Література}

1. Гончаренко С. Гуманізація i гуманітаризація освіти / С. Гончаренко, Ю. Мальований // Шлях освіти. - 2001. - № 3. - С. 2. 2. Каранська М. У. Синтаксис сучасної української літературної мови: [навч. посіб.] / М. У. Каранська. - К. : Либідь, 1995. - 312 c. 3. Язык образования и образование языка // Материалы международной научной конференции (Великий Новгород, 11-13 июня 2000 года). - Великий Новгород : НовГУ, 2000. -382 с.

УДК 37.013.42:37

Ірина Сизоненко

\section{АНАЛІЗ РЕЗУЛЬТАТІВ ПЕРЕВІРКИ ЕФЕКТИВНОСТІ ПРОЦЕСУ ПРАВОВОЇ СОЦАЛІЗАЦІЇ ДІТЕЙ-СИРІТ ПІДЛІТКОВОГО ВІКУ В ЗАГАЛЬНООСВІТНІЙ ШКОЛІ-ІНТЕРНАТІ}

Сизоненко І. Г. Аналіз результатів перевірки ефективності процесу правової соціалізації дітей-сиріт підліткового віку в загальноосвітній школі-інтернаті.

Статтю присвячено аналізу результатів дослідно-експериментальної перевірки ефективності процесу правової соціалізації дітей-сиріт підліткового віку в загальноосвітній школі-інтернаті. Якісний та кількісний аналіз продемонстрував позитивну динаміку правової соціалізації дітей-сиріт підліткового віку.

Ключові слова: модель, правова соціалізація, показники правової соціалізації, діти-сироти, підлітковий вік.

Сизоненко И. Г. Анализ результатов проверки эффективности процесса правовой социализации детей-сирот подросткового возраста в общеобразовательной школеинтернате.

В статье представлен анализ результатов экспериментальной проверки эффективности процесса правовой социализации детей-сирот подросткового возраста в общеобразовательной школе-интернате. Качественный и количественный анализ продемонстрировал положительную динамику правовой социализации детей-сирот подросткового возраста.

Ключевые слова: модель, правовая социализация, критерии, показатели правовой социализации, дети-сироты, подростковый возраст.

Sizonenko I. G. Analysis of results of verification of efficiency of process of legal socialization of children-orphans teens in general school, boarding school.

In the article the analysis of process of teen-orphans' legal socialization in boardingschool of general education is presented.

Key words: model, legal socialization, criteria, indicators of legal socialization, children-orphans, adolescence.

Загальноосвітні школи-інтернати як державні інститути виховання дітей-сиріт і дітей, позбавлених батьківського піклування, перебувають на стадії реформування, перепрофілювання, орієнтації на пріоритетність сімейних альтернативних форм влаштування дітей-сиріт. Реформаційні процеси, що відбуваються в системі інтернатної освіти, відповідно до Державної цільової соціальної програми реформування закладів для дітей-сиріт і дітей, позбавлених батьківського піклування [1], у період до 2017 року передбачають створення умов для реалізації 